\title{
Pencegahan Dini Kanker Payudara melalui Penyuluhan SADARI (Pemeriksaan Payudara Sendiri) pada Mahasiswi Uniska Banjarbaru Tahun 2019
}

\author{
Ridha Hayati ${ }^{1}$, Hilda Irianty ${ }^{2}$, Deni Suryanto ${ }^{3}$ \\ ${ }^{1,2,3}$ Fakultas Kesehatan Masyarakat Universitas Islam Kalimantan \\ Korespondensi Hafizulya22@gmail.com
}

Submitted : 20/06/2020

Accepted: 04/07/2020

Published: 24/11/2010

\begin{abstract}
Breast Self-Examination (BSE) is an important step for early detection of breast cancer and should begin when a woman has menstruated, with a sensitivity / ability to detect around 20-30\%. BPMUB is an organization where students from various faculties and forums gather to conduct community activities, with a total of 55 members, and is a representative of 9 faculties in Uniska Banjarbaru, 45\% of whom are women. Based on a questionnaire distributed to 25 BPMUB female members, 16 people knowledge of breast cancer were in the poor category, only 9 people were knowledgeable enough. In addition, awareness to do breast self-examination is still low, this is again due to lack of knowledge. The solution provided is awareness education for early detection of breast cancer, with a target audience of 50 people. The method used is lecture, demonstration and question and answer. The result of this activity was the real support from the Head of UPT UNISKA Banjarbaru and other faculty managers, enthusiasm from the target with attention and many questions both in activities and outside activities. Evaluation 2 weeks after socialization found 100\% answered all questionnaires about BSE correctly. This means an increase in knowledge of the respondents. Socialization by providing these skills needs to be carried out continuously.
\end{abstract}

Keywords: BSE, students, UNISKA

\begin{abstract}
Abstrak
Pemeriksaan Payudara Sendiri (SADARI) merupakan langkah penting untuk deteksi dini kanker payudara dan sebaiknya mulai dilakukan saat seorang wanita telah mengalami menstruasi, dengan tingkat sensitivitas/kemampuannya untuk mendeteksi sekitar 20-30\%. BPMUB merupakan organisasi yang menjadi tempat berkumpulnya mahasiswa dari berbagai fakultas dan wadah untuk melakukan kegiatan komunitas, dengan jumlah anggota 55 orang,dan merupakan perwakilan dari 9 fakultas yang ada di Uniska Banjarbaru, 45\% diantaranya adalah perempuan. Berdasarkan kuesioner yang di bagikan kepada 25 orang anggota BPMUB yang perempuan, 16 orang pengetahuan tentang kanker payudara dalam kategori kurang, hanya 9 orang berpengetahuan cukup. Selain itu kesadaran untuk melakukan pemeriksaan payudara sendiri masih rendah, hal ini kembali dikarenakan kurangnya pengetahuan. Solusi yang di berikan adalah Penyuluhan tentang sadari untuk deteksi dini kanker payudara, dengan jumlah khalayak sasaran 50 orang. Metode yang digunakan adalah ceramah, demonstrasi dan tanya jawab. Hasil dari kegiatan ini adalah adanya dukungan nyata dari Kepala UPT UNISKA Banjarbaru dan pengelola fakultas lain, antusiame dari sasaran dengan perhatian dan banyaknya pertanyaan baik di dalam kegiatan maupun diluar kegiatan. Evaluasi 2 minggu setelah sosialisasi ditemukan $100 \%$ menjawab benar semua kuesioner tentang SADARI. Ini berarti terjadi peningkatan pengetahuan pada responden. Sosialisasi dengan pemberian keterampilan ini perlu dilaksanakan secara kontinu.
\end{abstract}

Kata kunci : mahasiswa, SADARI, UNISKA

\section{PENDAHULUAN}

Pemeriksaan Payudara Sendiri (SADARI) merupakan langkah penting untuk deteksi dini kanker payudara. Mudah, murah, cepat, dan efektif untuk semangkin "mengenal" dan menyadari jika terdapat suatu hal yang tidak normal pada payudara/ benjolan yang kemungkinan besar berkembang menjadi kanker ganas dan sebaiknya mulai dilakukan saat seorang 
wanita telah mengalami menstruasi. Tingkat sensitivitas/ kemampuannya untuk mendeteksi sekitar 20-30\% (Nisman, 2011).

Berdasarkan data dari Sistem informasi Rumah Sakit (SIRS) 2010 : jumlah pasien kanker payudara sebanyak 21.014 orang $(28,7 \%)$ sehinggakanker payudara menjadi kasus kematian tertinggi di Indonesia. Data terakhir Kemenkes tanggal 31 Januari 2019, Angka kanker payudara 42,1/100.000 penduduk dengan rata-rata kematian 17/100.000 penduduk. Kasus kanker payudara saat ini juga banyak ditemukan pada usia muda yaitu mulai 15 tahun, 17, 19 tahun. Artinya sudah terjadi pergeseran di usia muda, kemungkinan karena gaya hidup, polusi, stress (Kemenkes, 2019).

Perjalanan kanker yang memakan waktu lama, sehingga perlu pencegahan semenjak usia dini, 96\% dari penderita kanker payudara didiagnosa terkena kanker payudara di atas 40 tahun (American Cancer Society, 2013). Mahasiswa adalah generasi penerus bangsa yang terpelajar, dan perwakilan mahasiswa salah satu organisasi yang menjadi tempat berkumpulnya mahasiswa dari berbagai fakultas dan wadah untuk melakukan kegiatan komunitas, Badan Persatuan Mahasiswa Uniska Banjar baru memiliki 55 anggota,dan merupakan perwakilan dari 9 fakultas yang ada di Uniska Banjarbaru 45\% diantaranya adalah perempuan. Pengetahuan anggota BPMUB tentang kanker payudara masih sangat minim, berdasarkan kuesioner yang di bagikan kepada 25 orang anggota BPMUB yang perempuan, 16 orang pengetahuan tentang kanker payudara dalam kategori kurang (jawaban benar $<70 \%$ ), hanya 9 orang berpengetahuan cukup (Jawaban benar 70-79\%). Selain itu kesadaran untuk melakukan pemeriksaan payudara sendiri masih rendah.

\section{TARGET DAN LUARAN}

Target pengabdian berupa penyuluhan Sadari yaitu anggota BPMUB (perempuan) yang berjumlah 50 orang. Luaran yang diharapkan adalah adanya peningkatan pengetahuan dan keterampilan pada sasaran dan lebih jauhnya dapat meneruskan informasi kepada orang lain. Luaran wajib adalah Publikasi di Jurnal dan media social.

\section{METODE PELAKSANAAN}

Pelaksanaan pengabdian ini dengan melakukan penyuluhan dengan metode ceramah, demonstrasi SADARI menggunakan maneqin dan tanya jawab. Adapun rencana pelaksanaan pengabdian sebagai berikut :

- Pendekatan kepada anggota BPMUB khususnya perempuan dengan membagikan kuesioner yang berisi 5 pertanyaan tentang kanker payudara

- Perizinan kepada Ketua BPMUB tentang pelaksanaan penyuluhan Sadari

- Menentukan jadwal pelaksanaan penyuluhan dengan ketua serta anggota BPMUB

- Rapat koordinasi dengan semua anggota tim pengabdian baik anggota dosen maupun mahasiswa

- Pelaksanaan kegiatan

- Evaluasi kepada sasaran pengabdian dengan membagikan kuesioner (pertanyaan sama dengan kuesioner awal)

\section{HASIL DAN PEMBAHASAN}

Kegiatan penyuluhan dilaksanakan pada hari selasa tanggal 17 desember 2019 dan evaluasi hari Senin tanggal 6 Januari 2020 dengan hasil sebagai berikut :

1. Dukungan dari kepala UPT UNISKA Banjarbaru dalam pelaksanaan kegiatan ini.

2. Dukungan dari pengelola fakultas lain dengan menghadiri kegiatan ini 
3. Antusis nya peserta kegiatan meskipun sosialisasi ini mirip seperti perkuliahan, hanya saja lebih atraktif karena disertai peragaan SADARI pada phantom dan tanya jawab yang lebih bebas, dan juga peserta dari berbagai fakultas.

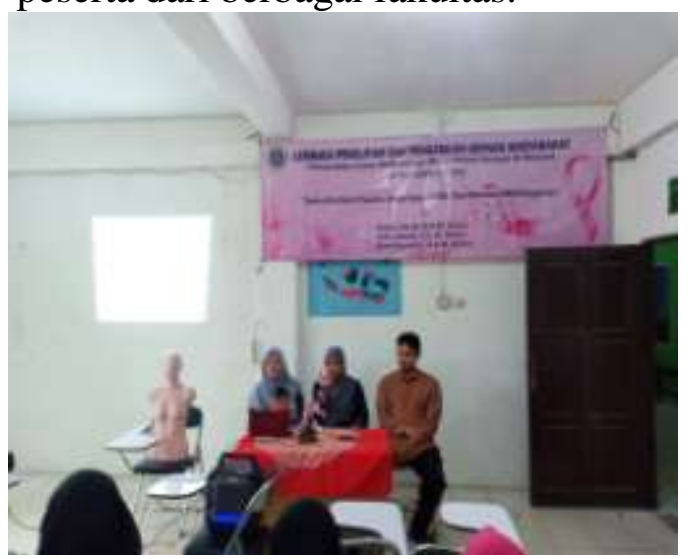

Gambar 1. Pembukaan acara penyuluhan

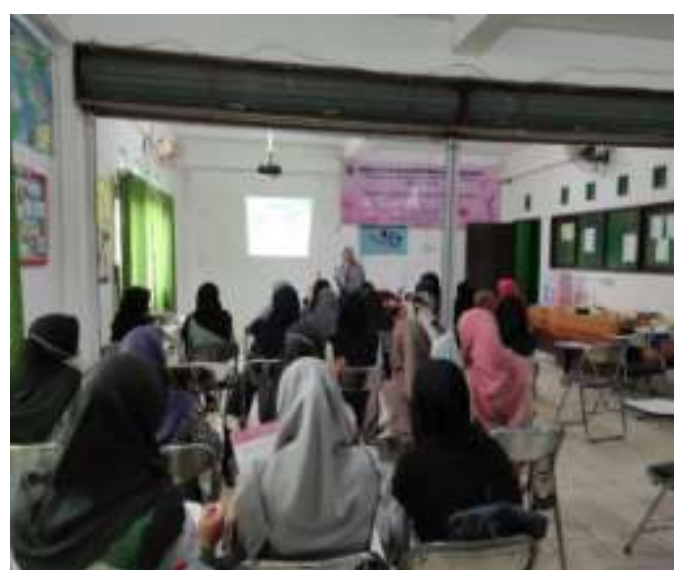

Gambar 2. Pemberian penyuluhan tentang SADARI

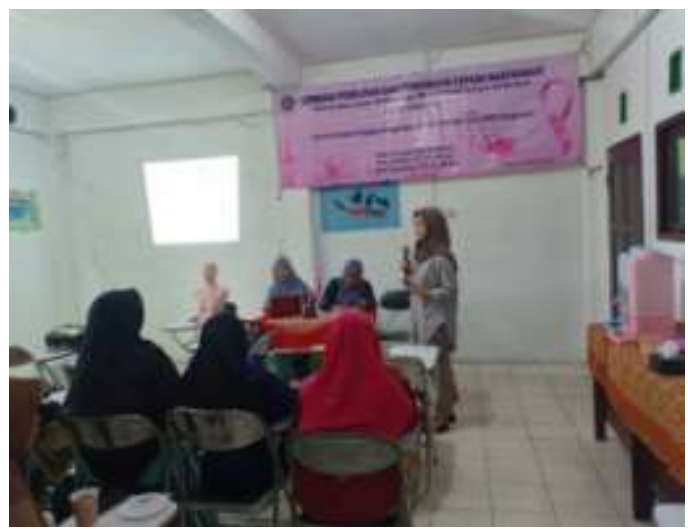

Gambar 3. Pertanyaan dari salah satu sasaran penyuluhan

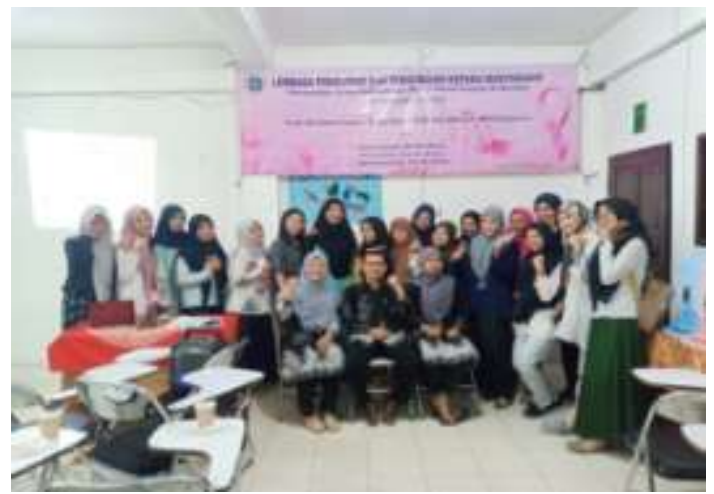

Gambar 4. Foto bersama dengan sebagian sasaran

4. Terlihat peningkatan pengetahuan yang sangat signifikan karena hampir semua responden memiliki pengetahuan dalan kategori baik setelah mengikuti kegiatan sosialisasi. Peningkatan pengetahuan tersebut bisa dilihat di tabel berikut :

Tabel 4.1 Peningkatan pengetahuan responden sosialisasi SADARI

\begin{tabular}{lllll}
\hline $\begin{array}{l}\text { Kategori } \\
\text { Pengetahuan }\end{array}$ & P1 & $\%$ & P2 & $\%$ \\
\hline Baik & 9 & 36 & 50 & 100 \\
Cukup & - & & & \\
Kurang & 16 & 64 & & \\
Jumlah & 30 & 100 & 50 & 100 \\
\hline
\end{tabular}

5. Artikel yang sudah dikirim ke jurnal pengabdian Jurnal Abdimas Kesehatan (JAK), Sekolah Tinggi Ilmu Kesehatan Baiturahim Jambi

\section{KESIMPULAN DAN SARAN}

\section{Kesimpulan}

Kegiatan sosialisasi SADARI meningkatkan pengetahuan sasaran, berdasarkan pre dan post test peningkatan pengetahuan sebesar $64 \%$. Metode penyuluhan ini sangat tepat untuk memberikan informasi secara cepat kepada sasaran, dan menarik karena disertai dengan demonstrasi SADARI pada maneqin.

\section{Saran}

Kegiatan sosialisasi perlu dilakukan secara berkelanjutan sehingga pengetahuan sasaran semakin baik, dan 
dengan sasaran para mahasiswa/i diharapkan mampu membawa perubahan bagi diri mereka sendiri dan mampu memberikan informasi lagi kepada kerabat terdekat bahkan ke masyarakat sekitar.

\section{UCAPAN TERIMA KASIH}

Terima kasih dari kami tim pelaksana pengabdian kepada Lembaga Penelitian dan Pengabdian kepada Masyarakat UNISKA yang telah mendukung secara adminstratif dan operasional dan terima kasih kepada BPMUB dan anggotanya yang bersedia menjadi sasaran penyuluhan.

\section{DAFTAR PUSTAKA}

American Cancer Society (ACS), 2011. Breast cancer facts \& figures 2010-2012.

Apriani, N.R, 2013. Hubungan tingkat pengetahuan tentang kanker payudara dengan tindakan memeriksa payudara sendiri (SADARI) pada siswi SMA Muhammadiyah Kasihan tahun 2013. Naskah Publikasi.Program Studi Bidan Pendidik jenjang DIV Sekolah Tinggi Ilmu Kesehatan 'Aisyiyah Yogyakarta.

Departemen Kesehatan Republik Indonesia, 2009. Buku saku pencegahan kanker leher rahim \& kanker payudara.

Kanita I, 2012, Gambaran pengetahuan tentang pengetahuan kanker payudara dan pola konsumsi isofla dari produk olahan kedelai pada siswi di SMAN 2 Tanggerang 2011. Skripsi. Program Studi Ilmu Keperawatan Fakultas Kedokteran dan Ilmu Kesehatan UIN Syarif Hidayatullah Jakarta.

KementrianKesehatan Republik Indonesia. (2019). Pusat data dan informasi Kementerian KesehatanRI. Http://www.depkes.go.id/resources/do wnload/pusdatin/infodatin/infodatinkanker.

Nisman W.A, 2011, Lima menit kenali payudara anda. Yogyakarta: CV. Andi Offset. 